\title{
Activa bestemd voor verkoop en beëindigde bedrijfsactiviteiten
}

\section{Dingeman Manschot en Ineke Kuiper}

SAMENVATTING In deze bijdrage wordt onderzocht in hoeverre de jaarrekeningen van ondernemingen uit de FTSE 100 voldoen aan de toelichtingsvoorschriften van IFRS 5 inzake activa bestemd voor verkoop en beëindigde bedrijfsactiviteiten. Naast het empirisch onderzoek met betrekking tot de kwaliteit van de naleving van deze voorschriften, worden best practices gepresenteerd. Uit ons onderzoek blijkt dat er met name ruimte is om de toegankelijkheid en inhoud van de informatie inzake beëindigde bedrijfsactiviteiten te verbeteren. Dat zal gebruikers van de jaarrekening beter in staat moeten stellen het effect van beëindigde bedrijfsactiviteiten op de omvang, timing en onzekerheden van toekomstige kasstromen te beoordelen.

\section{RELEVANTIE VOOR DE PRAKTIJK Dit artikel geeft de lezer inzicht in de wijze waarop de in IFRS 5 opgenomen toelichtingsvoorschriften op het gebied van activa bestemd voor} verkoop en beëindigde bedrijfsactiviteiten worden nageleefd door ondernemingen uit de FTSE 100. Opstellers, gebruikers en controleurs van jaarrekening kunnen dit artikel gebruiken om de door hen opgestelde, gebruikte en gecontroleerde jaarrekeningen op het gebied van verslaggeving van activa bestemd voor verkoop en beëindigde bedrijfsactiviteiten te benchmarken ten opzichte van beursgenoteerde ondernemingen binnen de Europese Unie.
Het doel van IFRS 5 is tweeledig. Enerzijds moet informatie worden verstrekt over activa die bestemd zijn voor verkoop. Anderzijds moet informatie worden verschaft over beëindigde bedrijfsactiviteiten. De verslaggeving van activa bestemd voor verkoop richt zich op de balans. Dit in tegenstelling tot de verslaggeving van beëindigde bedrijfsactiviteiten waarbij de focus juist ligt op de winst-en-verliesrekening en het kasstroomoverzicht. Beiden moeten gebruikers informatie geven waarmee zij zich een beeld kunnen vormen van toekomstige resultaten en kasstromen. Met andere woorden, gebruikers moeten het financiële effect van het afstoten van activa en beëindigde bedrijfsactiviteiten kunnen evalueren.

In paragraaf 2 wordt de opzet van het empirisch onderzoek en de selectie van de onderzoekspopulatie besproken. In paragraaf 3 besteden wij aandacht aan de verslaggeving van activa bestemd voor verkoop. In paragraaf 4 bespreken wij de verslaggeving van beëindigde bedrijfsactiviteiten. In beide paragrafen gaan wij per onderwerp in op de regelgeving, onze bevindingen en voorbeelden die wij als best practice beschouwen. Het artikel wordt in paragraaf 5 afgesloten met onze conclusies en afsluitende opmerkingen.

\section{Opzet empirisch onderzoek en selectie onderzoekspopulatie}

Het onderzoek gaat in op de verslaggeving van activa bestemd voor verkoop en beëindigde bedrijfsactiviteiten in jaarrekeningen van ondernemingen uit de FTSE 100 over het boekjaar 2011. Het onderzoek richt zich op de toepassing van de presentatie- en toelichtingsvoorschriften zoals opgenomen in IFRS 5 (hierna: IFRS 5 -voorschriften). Hierbij wordt de toepassing van de presentatie- en toelichtingsvoorschriften vastgelegd op basis van de informatie zoals verstrekt in de onderzochte jaarrekeningen.

Voor het bepalen van de onderzoekspopulatie is vastgesteld of in een jaarrekening van een onderneming uit de FTSE 100 over het boekjaar 2011 sprake is van activa (of disposal groepen) bestemd voor verkoop en/of beëindigde bedrijfsactiviteiten. Als een onderneming in haar jaarreke- 
ning geen activa (of disposal groepen) bestemd voor verkoop of beëindigde bedrijfsactiviteiten heeft gepresenteerd, dan valt de jaarrekening van deze onderneming niet binnen de onderzoekspopulatie van dit onderzoek. Van de jaarrekeningen in de onderzoekspopulatie is onderzocht hoe de presentatie en toelichting van activa (of disposal groepen) bestemd voor verkoop en/of beëindigde bedrijfsactiviteiten heeft plaatsgevonden.

Bij gebroken boekjaren is de jaarrekening 2010/2011 gehanteerd. Vervolgens is een selectie gemaakt van de ondernemingen die rapporteren op basis van International Financial Reporting Standards (IFRSs). Twee ondernemingen ( $A B B$ en Credit Suisse) uit de FTSE 100 rapporteren op basis van US GAAP en vallen derhalve buiten de reikwijdte van dit onderzoek. Tevens valt op te merken dat Unilever een dubbele vermelding heeft in de FTSE 100, omdat deze onderneming twee genoteerde holdings heeft. De uiteindelijke groep ( $\mathrm{N}_{1}$ in tabel 1 ) bestaat uit 97 ondernemingen uit de FTSE 100. De meeste ondernemingen zijn afkomstig uit het Verenigd Koninkrijk (26\%), gevolgd door Frankrijk (19\%) en Duitsland (15\%).

Binnen deze groep $\left(\mathrm{N}_{1}\right)$ is vastgesteld in welke jaarrekeningen over 2011 vaste activa (of disposal groepen) bestemd voor verkoop en/of beëindigde bedrijfsactiviteiten gepresenteerd zijn. Hieruit komt naar voren dat 50 jaarrekeningen uit deze groep (N1) binnen deze selectie vallen (onderzoekspopulatie $\mathrm{N}_{2}$ in tabel 1 ). Ook binnen deze selectie vindt het grootste deel van de ondernemingen haar herkomst in het Verenigd Koninkrijk (24\%). Dit land wordt

\section{Tabel 1 Samenstelling onderzoekspopulatie naar land van herkomst}

\begin{tabular}{|l|r|r|r|r|r|}
\hline Land & $\mathrm{N1}$ & $\% \mathrm{N1}$ & $\mathrm{N2}$ & $\% \mathrm{N2}$ & $\% \mathrm{~N} / \mathrm{N1} 1$ \\
\hline $\begin{array}{l}\text { Verenigd } \\
\text { Koninkrijk }\end{array}$ & 25 & $26 \%$ & 12 & $24 \%$ & $48 \%$ \\
\hline Frankrijk & 18 & $19 \%$ & 8 & $16 \%$ & $44 \%$ \\
\hline Duitsland & 14 & $15 \%$ & 6 & $12 \%$ & $43 \%$ \\
\hline Italï̈ & 7 & $7 \%$ & 6 & $12 \%$ & $86 \%$ \\
\hline Spanje & 7 & $7 \%$ & 5 & $10 \%$ & $71 \%$ \\
\hline Nederland & 5 & $5 \%$ & 5 & $10 \%$ & $100 \%$ \\
\hline Zwitserland & 8 & $8 \%$ & 3 & $6 \%$ & $38 \%$ \\
\hline Zweden & 6 & $6 \%$ & 2 & $4 \%$ & $33 \%$ \\
\hline Noorwegen & 2 & $2 \%$ & 1 & $2 \%$ & $50 \%$ \\
\hline Finland & 2 & $2 \%$ & 1 & $2 \%$ & $50 \%$ \\
\hline $\begin{array}{l}\text { Denemar- } \\
\text { ken }\end{array}$ & 2 & $2 \%$ & 1 & $2 \%$ & $50 \%$ \\
\hline België & 1 & $1 \%$ & 0 & $0 \%$ & $0 \%$ \\
\hline Totaal & 97 & $100 \%$ & 50 & $100 \%$ & $52 \%{ }^{*}$ \\
\hline
\end{tabular}

*) gemiddeld gevolgd door Frankrijk (16\%), Duitsland (12\%) en Italië (12\%).

In tabel 1 is tevens opgenomen de verhouding van de jaarrekeningen waarin sprake is van activa (of disposal groepen) bestemd voor verkoop en/of beëindigde bedrijfsactiviteiten ten opzichte van het totaal aantal jaarrekeningen per land binnen de FTSE 100. Hieruit blijkt dat in jaarrekeningen over 2011 van ondernemingen uit Nederland, Italië en Spanje relatief vaak sprake is van activa (of disposal groepen) bestemd voor verkoop en/of beëindigde bedrijfsactiviteiten. De onderzochte jaarrekeningen uit de onderzoekspopulatie $\left(\mathrm{N}_{2}\right)$ bevatten activa (of disposal groepen) bestemd voor verkoop en/of beëindigde bedrijfsactiviteiten.

Tabel 2 geeft een overzicht van de aanwezigheid van activa (disposal groups) bestemd voor verkoop en beëindigde bedrijfsactiviteiten in de jaarrekeningen uit de onderzoekspopulatie (N2). Hieruit blijkt dat het overgrote deel van de jaarrekeningen uit de onderzoekspopulatie $\left(\mathrm{N}_{2}\right)$ activa (of disposal groepen) bestemd voor verkoop bevat. Beeindigde bedrijfsactiviteiten komen in mindere mate voor in de onderzoekspopulatie (16 jaarrekeningen).

\section{Activa bestemd voor verkoop}

\subsection{Regelgeving}

Informatie over activa bestemd voor verkoop moet gebruikers helpen een inschatting te maken van de omvang, timing en onzekerheid van toekomstige kasstromen. Door classificatie van een actief als bestemd voor verkoop brengt een onderneming in haar balans tot uiting hoe de boekwaarde zal worden gerealiseerd. De boekwaarde zal naar verwachting worden gerealiseerd door verkoop van het actief en niet langer door het voortgezet gebruik van het actief door de onderneming. Een groep van activa (inclusief eventuele verplichtingen) kan ook gezamenlijk af-

\section{Tabel 2 Activa (of disposal groepen) bestemd voor verkoop en beëindigde bedriffsactiviteiten}

\begin{tabular}{|l|r|r|}
\hline & $\mathrm{n}$ & \% N2 \\
\hline $\begin{array}{l}\text { Alleen activa (of disposal groepen) bestemd voor ver- } \\
\text { koop }\end{array}$ & 34 & 68 \\
\hline Alleen beëindigde bedrifssactiviteiten & 3 & 6 \\
\hline $\begin{array}{l}\text { Zowel activa (of disposal groepen) bestemd voor ver- } \\
\text { koop als beëindigde bedriffsactiviteiten }\end{array}$ & 13 & 26 \\
\hline Totaal & 50 & 100 \\
\hline & \multicolumn{3}{|c|}{} \\
\hline Hieruit volgen de volgende populaties voor het onderzoek: & \multicolumn{2}{|l|}{} \\
\hline $\begin{array}{l}\text { Totaal aantal jaarrekeningen met beëindigde bedrijfs- } \\
\text { activiteiten }\end{array}$ & 16 & \\
\hline $\begin{array}{l}\text { Totaal aantal jaarrekeningen met activa (of disposal } \\
\text { groepen) bestemd voor verkoop }\end{array}$ & 47 & \\
\hline
\end{tabular}


gestoten worden. In dat geval is er sprake van een disposal groep. De waardering van een vast actief of disposal groep als bestemd voor verkoop vindt plaats tegen de laagste van de boekwaarde en reële waarde minus verkoopkosten. Op die wijze wordt direct een eventueel verwacht verlies bij verkoop zichtbaar gemaakt. Een vast actief of een disposal groep classificeert als bestemd voor verkoop als de boekwaarde ervan hoofdzakelijk zal worden gerealiseerd in een verkooptransactie en niet door het voortgezette gebruik ervan. Voorwaarden voor classificatie als bestemd voor verkoop zijn (IFRS 5.7):

- het actief (of disposal groep) moet in zijn huidige staat onmiddellijk beschikbaar zijn voor verkoop en onderworpen zijn aan bepalingen die gebruikelijk zijn voor de verkoop van dergelijke activa (of disposal groepen); en - de verkoop moet zeer waarschijnlijk zijn.

Zeer waarschijnlijk is een kans die aanmerkelijk groter is dan waarschijnlijk (IFRS 5 .A). In IFRS 5 zijn nadere criteria opgenomen om vast te stellen wanneer een verkoop zeer waarschijnlijk is. Deze bepalingen moeten de subjectiviteit rond de intentie van management inperken. Met andere woorden, deze specifieke criteria hebben als doel om de classificatie van activa bestemd voor verkoop te objectiveren. Van een zeer waarschijnlijke verkoop is sprake als (IFRS 5.8):

- het management zich heeft gecommitteerd aan een plan voor de verkoop van het actief (of disposal groep);

- een operationeel plan om een koper te vinden en het plan te voltooien, opgestart is;

- het actief (of disposal groep) op actieve wijze voor verkoop op de markt wordt gebracht tegen een prijs die redelijk is ten opzichte van zijn reële waarde;

- de verkoop naar verwachting gerealiseerd zal worden binnen één jaar na de datum van de classificatie; en

- handelingen die nodig zijn om het plan te voltooien aangeven dat het onwaarschijnlijk is dat belangrijke wijzigingen aan het plan zullen worden aangebracht of dat het plan zal worden ingetrokken.

\subsection{Empirisch onderzoek en best practices}

\subsubsection{Frequentie voorkomen van activa (of disposal groepen) bestemd voor verkoop}

Activa (of disposal groepen) bestemd voor verkoop komen in 47 jaarrekeningen van de onderzoekspopulatie voor. In 32 jaarrekeningen komen tevens verplichtingen voor die behoren tot disposal groepen (zie tabel 3).

Ondanks dat in de onderzochte jaarrekeningen niet altijd duidelijk wordt aangegeven of het gaat om een actief of een disposal groep, biedt de aanwezigheid van hieraan gerelateerde verplichtingen een anwijzing dat er sprake is van een disposal groep. Er kan dan ook worden gesteld dat in de meeste jaarrekeningen sprake is van disposal groepen (zie tabel 4).
Aangezien bij activa (of disposal groepen) bestemd voor verkoop sprake kan zijn van een relatief kleine omvang die vanuit het perspectief van de gebruiker aangemerkt kan worden als niet materieel, ${ }^{2}$ wordt er in dit onderzoek rekening gehouden met een tolerantie. De gehanteerde tolerantie bedraagt voor activa (of disposal groepen) bestemd voor verkoop $0,5 \%$ van de totale activa. Benadrukt wordt dat deze grens arbitrair is en niet betekent dat alle posten groter dan of gelijk aan $0,5 \%$ materieel zijn, of dat alle posten beneden de $0,5 \%$ niet materieel zijn. Deze grens moet helpen bij het analyseren van de bevindingen. Bij het vaststellen van de toepassing van de IFRS 5-voorschriften is onderscheid gemaakt tussen de onderzoekspopulatie en de jaarrekeningen die posten boven deze tolerantie bevatten.

Binnen activa (of disposal groepen) bestemd voor verkoop is er veel verscheidenheid in de relatieve omvang van de activa die als zodanig gepresenteerd is. Van de 47 ondernemingen die activa (of disposal groepen) bestemd voor verkoop in hun balans presenteren, is bij 13 ondernemingen $(28 \%)$ de desbetreffende actiefpost hoger dan of gelijk aan $0,5 \%$ van het balanstotaal (zie tabel 5 ).

\section{Tabel 3 Activa en verplichtingen bestemd voor verkoop}

\begin{tabular}{|l|r|r|}
\hline & $\mathrm{n}$ & $\%$ \\
\hline Alleen activa bestemd voor verkoop & 15 & 32 \\
\hline Zowel activa als verplichtingen bestemd voor verkoop & 32 & 68 \\
\hline Totaal & 47 & 100 \\
\hline
\end{tabular}

\section{Tabel 4 Indeling activa bestemd voor verkoop naar categorieën}

\begin{tabular}{|l|r|r|}
\hline & $\mathrm{n}$ & $\%$ \\
\hline Alleen individuele vaste activa & 14 & 30 \\
\hline Alleen disposal groepen & 7 & 15 \\
\hline Zowel individuele vaste activa als disposal groepen & 5 & 11 \\
\hline Niet gespecificeerd, wel verplichtingen opgenomen & 20 & 43 \\
\hline Indeling niet mogelijk & 1 & 2 \\
\hline Totaal & 47 & 100 \\
\hline
\end{tabular}

\section{Tabel 5 Activa bestemd voor verkoop ten opzichte van de tolerantie $(0,5 \%)$}

\begin{tabular}{|l|r|r|}
\hline & $\mathrm{n}$ & $\%$ \\
\hline Omvang boven tolerantie & 13 & 28 \\
\hline Omvang beneden tolerantie & 34 & 72 \\
\hline Totaal & 47 & 100 \\
\hline
\end{tabular}




\subsubsection{Presentatie van activa (of disposal groepen) bestemd voor verkoop}

Een onderneming moet een vast actief geclassificeerd als bestemd voor verkoop (of de activa van een disposal groep) afzonderlijk van andere activa in de balans presenteren (IFRS 5.38). IFRS 5 bepaalt niet dat activa bestemd voor verkoop wel of niet als vlottend moeten worden gepresenteerd. De verplichtingen van een disposal groep moeten afzonderlijk van andere verplichtingen in de balans worden gepresenteerd. Deze activa en verplichtingen mogen niet worden gesaldeerd en gepresenteerd als een enkelvoudig bedrag.

De presentatie van activa (of disposal groepen) bestemd voor verkoop in de balans verschilt tussen de onderzochte jaarrekeningen. Dit verschil wordt met name veroorzaakt door de wijze waarop een onderneming haar balans presenteert. In de balans kan onderscheid gemaakt worden tussen vast en vlottend of de balans is opgesteld op basis van liquiditeit. In de meeste jaarrekeningen zijn de activa en verplichtingen bestemd voor verkoop opgenomen on-

\section{Figuur 1 Best practice: SABMiller plc Annual Report 2011, p. 80}

\begin{tabular}{|c|c|c|c|}
\hline & Notes & $\begin{array}{c}2011 \\
\text { us\$m }\end{array}$ & $\begin{array}{l}20101 \\
\text { ussm }\end{array}$ \\
\hline \multicolumn{4}{|l|}{$\begin{array}{l}\text { Assets } \\
\text { Non-current assets }\end{array}$} \\
\hline Goodwill & 10 & 11,952 & 11,579 \\
\hline Intangble assets & 11 & 4,361 & 4,354 \\
\hline Property, plart and equipment & 12 & 9,330 & 8,915 \\
\hline Irvestments in joint ventures & 13 & 5,813 & 5,822 \\
\hline Investments in associates & 14 & 2,719 & 2,213 \\
\hline Available for sale investments & 15 & 35 & 31 \\
\hline Derivative financial instruments & 24 & 330 & 400 \\
\hline Trade and other recaivables & 17 & 140 & 117 \\
\hline \multirow[t]{2}{*}{ Deferred tax assets } & 21 & 184 & 164 \\
\hline & & 34,864 & 33,604 \\
\hline \multicolumn{4}{|l|}{ Current assets } \\
\hline 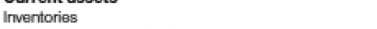 & 16 & 1,256 & 1,296 \\
\hline Trade and other recoivablas & 17 & 1,687 & 1,665 \\
\hline Current tax assets & & ${ }_{152}^{7,007}$ & 135 \\
\hline Derivative firancial instruments & 24 & 16 & 20 \\
\hline Available for sale irvestments & 15 & - & 1 \\
\hline \multirow{2}{*}{$\begin{array}{l}\text { Cash and cash equivalents } \\
\end{array}$} & 18 & 1,067 & 779 \\
\hline & & 4,178 & 3,906 \\
\hline \multirow[t]{2}{*}{ Assets of disposal group classiffed as held for sale } & 19 & 06 & \\
\hline & & 4,244 & 3,896 \\
\hline Total assets & & 39,106 & 37,499 \\
\hline \multirow{2}{*}{\multicolumn{4}{|c|}{$\begin{array}{l}\text { Liabilities } \\
\text { Current liabilities }\end{array}$}} \\
\hline & & & \\
\hline $\begin{array}{l}\text { Derivative financial instruments } \\
\text { Borrowings }\end{array}$ & ${ }_{22}^{24}$ & $\begin{aligned}(50) \\
(1,345)\end{aligned}$ & $\begin{array}{l}(174) \\
(1605)\end{array}$ \\
\hline $\begin{array}{l}\text { Borrowings } \\
\text { Trade and other payables }\end{array}$ & 20 & $(3,484)$ & $(3,228)$ \\
\hline \multirow{3}{*}{ Provisions } & & $(656)$ & $(616)$ \\
\hline & 25 & $(410)$ & (355) \\
\hline & & $(5,947)$ & $(5,978)$ \\
\hline \multirow[t]{2}{*}{ Liabilities of disposal group dlassifid as held for sale } & 19 & (86) & \\
\hline & & $(6,013)$ & $(5,978)$ \\
\hline \multicolumn{4}{|l|}{ Non-current liabilities } \\
\hline Derivative financial instrurnents & 24 & (85) & $(147)$ \\
\hline $\begin{array}{l}\text { Borrowings } \\
\text { B }\end{array}$ & 22 & $(7,115)$ & $(7,809)$ \\
\hline Trade and other payables & 20 & (96) & (145) \\
\hline Deferred tax liabilities & 21 & $(2,578)$ & $(2,374)$ \\
\hline \multirow[t]{2}{*}{$\begin{array}{l}\text { Provisions } \\
\end{array}$} & 25 & $(400)$ & (453) \\
\hline & & $(10,336)$ & $(10,928)$ \\
\hline Total liabilities & & $(16,349)$ & $(16,906)$ \\
\hline Net assets & & 22,759 & 20,598 \\
\hline \multicolumn{4}{|l|}{ Equity } \\
\hline Share capital & 26 & 166 & 165 \\
\hline Share premium & & 6,364 & 6,312 \\
\hline Merger relief reserve & & 4,506 & 4,586 \\
\hline Other reserves & $27 \mathrm{~b}$ & 1,881 & 1,322 \\
\hline Retained earnings & $27 \mathrm{a}$ & 8,991 & 7,525 \\
\hline Total shareholders' equity & & 22,008 & 19,910 \\
\hline Non-controling interests & & 751 & 683 \\
\hline Total equity & & 22,759 & 20,593 \\
\hline
\end{tabular}

der de vlottende activa en kortlopende verplichtingen (zie tabel 6).

Als een onderneming een balans opstelt waarbij onderscheid wordt gemaakt tussen vaste en vlottende posten worden de activa (of disposal groepen) bestemd voor verkoop in de meeste gevallen als onderdeel van de vlottende activa gepresenteerd als assets (classified as) held for sale of assets of disposal groups. In vijf jaarrekeningen zijn de activa bestemd voor verkoop separaat als hoofdcategorie weergegeven naast de vaste en vlottende activa. Dat betekent dat geen onderscheid gemaakt wordt tussen vast en vlottend.

Een duidelijke weergave van de activa bestemd voor verkoop is te vinden in de jaarrekening van SABMiller. Hierin wordt deze post op een afzonderlijke regel weergegeven onder de vlottende activa. Onder deze regel volgt vervolgens een subtotaal van de vlottende activa. Hetzelfde is gedaan bij de verplichtingen van disposal groepen.

\subsubsection{Categorië̈n activa en verplichtingen geclassificeerd als bestemd voor verkoop}

In jaarrekeningen met activa (of disposal groepen) bestemd voor verkoop dienen de belangrijkste categorieën activa en verplichtingen geclassificeerd als bestemd voor verkoop afzonderlijk te worden vermeld; ofwel in de toelichting ofwel in de balans (IFRS 5.38). In een voorbeeld bij IFRS 5 worden de volgende categorieën genoemd: materiële vaste activa, investeringen in eigenvermogensinstrumenten en verplichtingen (IFRS 5, Example 12). Dit voorbeeld geeft enig houvast over hetgeen de IASB onder categorieën verstaat. Bij 25 jaarrekeningen (53\%) uit dit onderzoek is uitsplitsing naar categorieën terug te vinden voor de gebruiker (zie tabel 7). Dit is relatief weinig. Ook bij de categorisering van verplichtingen is een soortgelijke verdeling te

\section{Tabel 6 Presentatie van activa bestemd voor verkoop en bijbehorende verplichtingen in de balans}

\begin{tabular}{|l|r|r|r|r|r|r|}
\hline \multicolumn{2}{|c|}{ Activa (n) } & \multicolumn{2}{|c|}{$\%$} & $\begin{array}{c}\text { Verplich- } \\
\text { tingen (n) }\end{array}$ & $\%$ \\
\hline $\begin{array}{l}\text { Onderscheid vast//lottend in de } \\
\text { balans: }\end{array}$ & & & & & & \\
\hline $\begin{array}{l}\text { - Onder de vlottende activa/kortlo- } \\
\text { pende verplichtingen }\end{array}$ & 24 & & & 12 & & \\
\hline $\begin{array}{l}\text { - Onder subtotaal van vlottende } \\
\text { activa/kortlopende verplichtingen }\end{array}$ & 5 & & & 3 & & \\
\hline $\begin{array}{l}\text { - Categorie separaat van de (vaste/ } \\
\text { vlottende) activa/(langlopende/kort- } \\
\text { lopende) verplichtingen }\end{array}$ & 5 & & & 6 & & \\
\hline - Anders & 2 & & & 0 & & \\
\hline $\begin{array}{l}\text { Totaal onderscheid vast/vlottend in } \\
\text { de balans }\end{array}$ & & 36 & 77 & & 23 & 72 \\
\hline Balans op basis van liquiditeit & & 11 & 23 & & 9 & 28 \\
\hline Totaal & & 47 & 100 & & 32 & 100 \\
\hline
\end{tabular}


vinden. Dit kan worden veroorzaakt door een verschil in interpretatie van de belangrijkste categorieën activa en verplichtingen. De verschillen betreffen:

- een overzicht per balanscategorie (bijvoorbeeld materiële vaste activa, immateriële vaste activa en financiële vaste activa);

- het onderscheid tussen vast en vlottend;

- een toelichting op de grootste elementen (bijvoorbeeld goodwill, vastgoedbeleggingen en investeringen in eigenvermogensinstrumenten).

In de jaarrekeningen die de belangrijkste categorieën en verplichtingen in de toelichting niet expliciet noemen, kan veelal wel worden teruggevallen op de toelichting van de andere balansposten. Dit aangezien in de meeste gevallen daar de overboekingen naar activa (of disposal groepen) bestemd voor verkoop worden weergegeven. Hieruit kan wel worden opgemaakt dat de toelichting op dit punt vatbaar is voor verbetering, aangezien de gebruiker hiermee niet altijd direct inzicht verkrijgt in de belangrijkste categorieën activa en verplichtingen die geclassificeerd zijn als bestemd voor verkoop.

De jaarrekeningen die geen uitsplitsing bevatten betreffen op één uitzondering na posten die beneden de tolerantie van $0,5 \%$ zijn. Derhalve zou er een verband kunnen zijn

\section{Tabel 7 Vermelding belangrijkste categorieën activa die zijn geclassificeerd als bestemd voor verkoop}

\begin{tabular}{|l|r|r|r|}
\hline & \multicolumn{2}{|c|}{$n$} & $\%$ \\
\hline Activa bestemd voor verkoop zonder uitsplitsing: & & & \\
\hline - waarvan omvang boven tolerantie & 1 & & \\
\hline - waarvan omvang beneden tolerantile & 17 & & \\
\hline Totaal activa bestemd voor verkoop zonder uitsplitsinn & & 18 & 38 \\
\hline $\begin{array}{l}\text { Activa bestemd voor verkoop met uitsplitsing } \\
\text { vast/vlottend }\end{array}$ & & 4 & 9 \\
\hline $\begin{array}{l}\text { Activa bestemd voor verkoop met uitsplitsing naar } \\
\text { balansposten }\end{array}$ & & 25 & 53 \\
\hline Totaal & & 47 & 100 \\
\hline & & & \\
\hline Categorieën: & & & \\
\hline - Immaterïle vast activa & & 35 & 74 \\
\hline - Materiële vaste activa & & 25 & 53 \\
\hline - Financiële vaste activa & & 4 & 9 \\
\hline - Belastinglatenties & & 4 & 9 \\
\hline - Voorraden & & 10 & 21 \\
\hline - Vorderingen & & 7 & 15 \\
\hline - Liquide middelen & & 7 & 15 \\
\hline - Diverse posten & & 17 & 4 \\
\hline - Niet gespecificeerd & & & 36 \\
\hline
\end{tabular}

tussen de relatief beperkte omvang van de post in de jaarrekening en het ontbreken van de uitsplitsing.

Van de jaarrekeningen die een vermelding van de categorieën bevatten, betreft een groot deel de immateriële en materiële vaste activa. Bij verplichtingen gaat het hier met name om de voorzieningen en leningen/deposito's.

ENEL geeft een goed voorbeeld van de splitsing naar de belangrijkste categorieën van activa en verplichtingen. In aanvulling daarop geeft zij tevens het verloop van de activa en verplichtingen weer. Hierbij wordt onderscheid gemaakt naar reclassificaties tussen vast en vlottend, verkopen en consolidatie-effecten en andere wijzigingen.

\subsubsection{Beschrijving van het actief (of disposal groep) bestemd voor verkoop}

De jaarrekening over de periode waarin het actief (of disposal groep) aangemerkt wordt als bestemd voor verkoop of wordt verkocht dient een beschrijving van het actief (of disposal groep) te bevatten (IFRS 5.41 onder a). In negen jaarrekeningen $(19 \%)$ is niet een dergelijke vermelding opgenomen (zie tabel 9). Het niet opnemen van een beschrijving van het vast actief (of disposal groep) zou veroorzaakt kunnen zijn door het toepassen van materialiteit bij het opstellen van de jaarrekening. Dit wordt ondersteund door nadere analyse waaruit blijkt dat het bij alle jaarrekeningen zonder beschrijving gaat om een omvang beneden de tolerantie van 0,5\%.

\section{Figuur 2 Best practice: ENEL Annual Report 2011, pp. 245-246}

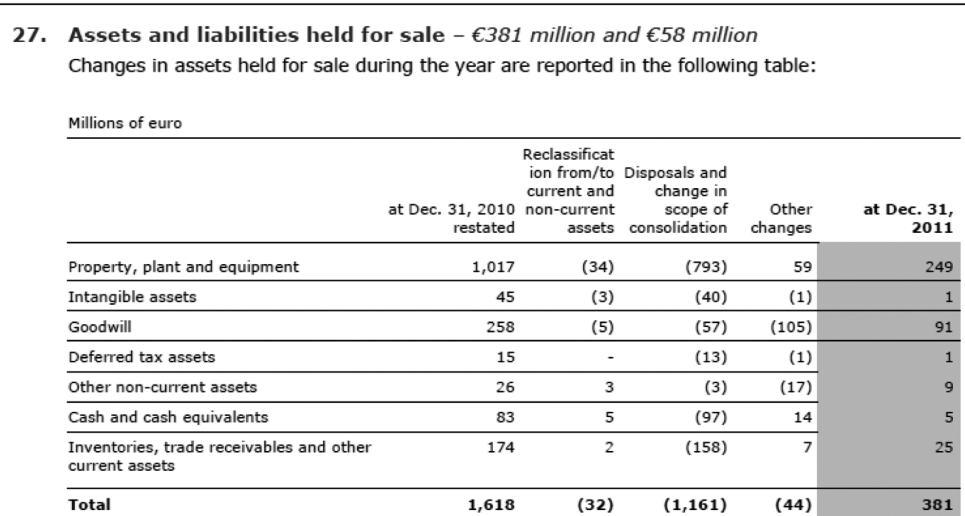

Changes in liabilities held for sale during the year are as follows:

Millions of euro

\begin{tabular}{|c|c|c|c|c|c|}
\hline & $\begin{array}{r}\text { at Dec. } 31,2010 \\
\text { restated }\end{array}$ & $\begin{array}{r}\text { Reclassification } \\
\text { from current and } \\
\text { non-current } \\
\text { liabilities } \\
\end{array}$ & $\begin{array}{r}\text { Disposals } \\
\text { and change } \\
\text { in scope of } \\
\text { consolidatio } \\
n\end{array}$ & $\begin{array}{r}\text { Other } \\
\text { changes }\end{array}$ & $\begin{array}{r}\text { at Dec. 31, } \\
2011\end{array}$ \\
\hline Long-term loans & 400 & - & (399) & & 1 \\
\hline $\begin{array}{l}\text { Post-employment and other } \\
\text { employee benefits }\end{array}$ & 4 & - & (3) & - & 1 \\
\hline Provisions for risks and charges & 62 & - & (16) & (16) & 30 \\
\hline Deferred tax liabilities & 30 & - & (11) & - & 19 \\
\hline Other non-current liabilities & 32 & - & (31) & (1) & - \\
\hline Short-term loans & 330 & - & (329) & - & 1 \\
\hline $\begin{array}{l}\text { Trade payables and other current } \\
\text { liabilities }\end{array}$ & 140 & 3 & (112) & (25) & 6 \\
\hline Total & 998 & 3 & (901) & (42) & 58 \\
\hline
\end{tabular}


Een goed voorbeeld van de toelichting op activa bestemd voor verkoop is te vinden in de jaarrekening van BBVA. Hierin is specifiek aandacht besteed aan de aard van de desbetreffende activa.

\subsubsection{Redenen voor classificatie als activa bestemd voor verkoop}

Ook de achtergrond van een voorgenomen verkoop is relevante informatie voor de gebruiker. Er kunnen immers verschillende redenen zijn om activa of groepen activa af te stoten. IFRS 5 vereist dat de jaarrekening een beschrijving dient te bevatten van de feiten en omstandigheden van de verkoop, of die zullen leiden tot de verwachte verkoop, en de wijze en het tijdstip waarop de verkoop naar verwachting zal plaatsvinden (IFRS 5.41 onder b).

Van de 47 jaarrekeningen waarin activa (of disposal groepen) bestemd voor verkoop zijn opgenomen beschrijven 13 jaarrekeningen $(27 \%)$ de feiten en omstandigheden van de verkoop, of die zullen leiden tot de verwachte verkoop (zie tabel 10). In de jaarrekeningen waarin een vast actief (of disposal groep) wordt opgenomen, wordt in 34 jaarrekeningen ( $73 \%$ ) geen beschrijving van de feiten en omstandigheden van de (verwachte) verkoop opgenomen. Het niet opnemen van deze beschrijving zou veroorzaakt kunnen zijn door het toepassen van materialiteit bij het opstellen van de jaarrekening. Uit nadere analyse blijkt dat $79 \%$ van de jaarrekeningen een post bevat die onder de tolerantie valt zoals gehanteerd in dit artikel. Aan de an-

\section{Figuur 3 Best practice: BBVA Annual Report 2011, note 16}

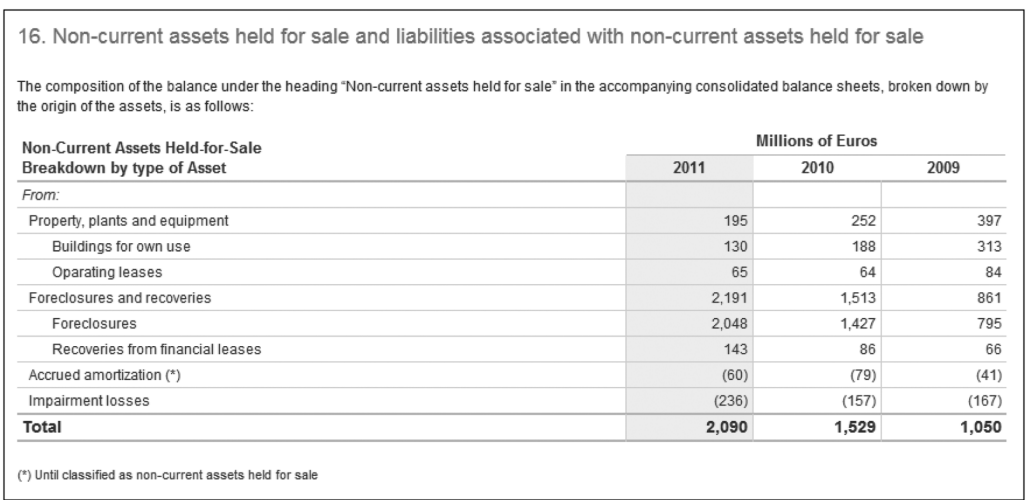

\section{Tabel 9 Beschrijving van het vast actief (of disposal groep)}

\begin{tabular}{|l|r|r|r|}
\hline & \multicolumn{2}{|c|}{$n$} & $\%$ \\
\hline Geen vermelding beschrijining vast actief (of disposal groep): & & & \\
\hline - waarvan omvang boven tolerantile & 0 & & \\
\hline - waarvan omvang beneden tolerantie & 9 & & \\
\hline Totaal geen vermelding beschrijiving vast actief (of disposal groep) & & 9 & 19 \\
\hline Vermelding beschrijiving vast actief (of disposal groep) & & 38 & 81 \\
\hline Totaal & & 47 & 100 \\
\hline
\end{tabular}

dere kant zijn er nog steeds zeven jaarrekeningen die activa bestemd voor verkoop van grote omvang bevatten en geen reden voor verkoop daarbij vermelden (15\%).

Toelichtingen op activa bestemd voor verkoop verschillen van een korte beschrijving tot meer uitgebreide beschrijvingen. De jaarrekening van BP bevat bijvoorbeeld een chronologische beschrijving van de gebeurtenissen die zich in het boekjaar hebben voorgedaan. Hierbij worden verschillende aspecten van de disposal groepen bestemd voor verkoop belicht.

\subsubsection{Segmentatie van activa (of disposal groepen) bestemd voor verkoop}

IFRS 5 vereist ook toelichting van activa (of disposal groepen) bestemd voor verkoop per te rapporteren segment in lijn met IFRS 8 (IFRS 5.41 onder d). In zes jaarrekeningen zijn activa (of disposal groepen) bestemd voor verkoop weergegeven in het gesegmenteerde overzicht (zie tabel 11). Bij een deel van deze jaarrekeningen valt dit indirect op te maken uit de toelichting op de activa bestemd voor verkoop. Het niet opnemen van deze segmentinformatie zou mogelijk verband kunnen houden met het toepassen van materialiteit bij het opstellen van de jaarrekening. Bij het toepassen daarvan blijkt echter dat er nog steeds een deel van de jaarrekeningen een post boven de tolerantie bevat $(17 \%)$.

\section{Tabel 8 Vermelding belangrijkste categorieën verplichtingen die zijn geclassificeerd als bestemd voor verkoop}

\begin{tabular}{|l|r|r|r|}
\hline & \multicolumn{2}{|c|}{$n$} & $\%$ \\
\hline $\begin{array}{l}\text { Verplichtingen bestemd voor verkoop zonder uit- } \\
\text { splitsing: }\end{array}$ & & & \\
\hline - waarvan omvang boven tolerantie & 0 & & \\
\hline - waarvan omvang beneden tolerantie & 9 & & \\
\hline $\begin{array}{l}\text { Totaal verplichtingen bestemd voor verkoop zonder } \\
\text { uitsplitsing }\end{array}$ & & 9 & 28 \\
\hline $\begin{array}{l}\text { Verplichtingen bestemd voor verkoop met uitsplit- } \\
\text { sing langlopend/kortlopend }\end{array}$ & & 2 & 6 \\
\hline $\begin{array}{l}\text { Verplichtingen bestemd voor verkoop met uitsplit- } \\
\text { sing naar balansposten }\end{array}$ & & 21 & 66 \\
\hline Totaal & & 32 & 100 \\
\hline & & & \\
\hline Categorieën: & & & \\
\hline - Voorzieningen & & 13 & 41 \\
\hline - Belastinglatenties & & 4 & 13 \\
\hline - Leningen en deposito's & & 13 & 41 \\
\hline - Handelscrediteuren & & 9 & 28 \\
\hline - Diverse posten & & 3 & 9 \\
\hline - Niet gespecificeerd & & 15 & 47 \\
\hline
\end{tabular}




\section{Tabel 10 Redenen voor classificatie activa als bestemd voor verkoop}

\begin{tabular}{|l|r|r|r|r|}
\hline & \multicolumn{2}{|c|}{$N$} & \multicolumn{2}{|c|}{$\%$} \\
\hline Desinvesteringsstrategie & & 5 & & 11 \\
\hline Buitengebruikstelling & & 3 & & 6 \\
\hline Reorganisatie & & 2 & & 4 \\
\hline Executiegoederen & & 1 & & 2 \\
\hline Marktregulering & & 1 & & 2 \\
\hline Waardecreatie voor aandeelhouders & & 1 & & 2 \\
\hline Reden ontbreekt: & & & & \\
\hline - waarvan omvang boven tolerantie & 7 & & 15 & \\
\hline - waarvan omvang beneden tolerantie & 27 & & 58 & \\
\hline Totaal zonder vermelding reden & & 34 & & 73 \\
\hline Totaal & & 47 & & 100 \\
\hline
\end{tabular}

\section{Beëindigde bedrijfsactiviteiten}

\subsection{Regelgeving}

De resultaten en kasstromen van beëindigde bedrijfsactiviteiten moeten afzonderlijk worden getoond. Dit is nodig om gebruikers in staat te stellen een oordeel te vormen over de resultaten en kasstromen van enerzijds de beeindigde bedrijfsactiviteiten en anderzijds de doorlopende bedrijfsactiviteiten. Dit onderscheid moet gebruikers helpen een inschatting te maken van de toekomstige resultaten en kasstromen van de onderneming.

Een beëindigde bedrijfsactiviteit is een component van een onderneming die ofwel is afgestoten, ofwel is geclassificeerd als bestemd voor verkoop, en (IFRS 5.32):

- een afzonderlijke belangrijke bedrijfsactiviteit of geografisch bedrijfsgebied vertegenwoordigt;

- deel uitmaakt van één enkel gecoördineerd plan om een afzonderlijke belangrijke bedrijfsactiviteit of geografisch bedrijfsgebied af te stoten; of

- een dochteronderneming is die uitsluitend is overgenomen met de bedoeling te worden doorverkocht.

Een component van een onderneming betreft bedrijfsactiviteiten en kasstromen die operationeel en voor financiele-verslaggevingsdoeleinden duidelijk kunnen worden onderscheiden van de rest van de onderneming (IFRS 5.31). Het betreft een kasstroomgenererende eenheid of een groep van kasstroomgenererende eenheden.

Een disposal groep bestemd voor verkoop classificeert niet per definitie als een beëindigde bedrijfsactiviteit. Om als beëindigde bedrijfsactiviteit te classificeren moet de disposal groep een afzonderlijke belangrijke bedrijfsactiviteit of geografisch bedrijfsgebied vertegenwoordigen of deel uitmaken van één enkel gecoördineerd plan om een afzon-

\section{Tabel 11 Segmentatie van activa (of disposal groepen) bestemd voor verkoop}

\begin{tabular}{|l|r|r|r|r|}
\hline & \multicolumn{2}{|c|}{$n$} & \multicolumn{2}{c|}{$\%$} \\
\hline $\begin{array}{l}\text { Geen presentatie activa bestemd voor ver- } \\
\text { koop in het gesegmenteerde overzicht: }\end{array}$ & & & & \\
\hline - waarvan omvang boven tolerantie & 8 & & 17 & \\
\hline - waarvan omvang beneden tolerantie & 33 & & 70 & \\
\hline $\begin{array}{l}\text { Totaal geen presentatie activa bestemd voor } \\
\text { verkoop in het gesegmenteerde overzicht }\end{array}$ & & 41 & & 87 \\
\hline $\begin{array}{l}\text { Presentatie activa bestemd voor verkoop } \\
\text { in het gesegmenteerde overzicht }\end{array}$ & & 6 & & 13 \\
\hline Totaal & & & & \\
\hline & & & & 100 \\
\hline Segmentatiebasis (meerdere mogelijk): & & & & \\
\hline - Geografisch & & 4 & & 9 \\
\hline - Aard van service/product & & 3 & & 6 \\
\hline - Activa & & 1 & & 2 \\
\hline
\end{tabular}

derlijke belangrijke bedrijfsactiviteit of geografisch bedrijfsgebied af te stoten. Op die wijze wordt voorkomen dat ook relatief kleine disposal groepen als beëindigde bedrijfsactiviteiten zouden moeten worden gepresenteerd en toegelicht.

\section{Figuur 4 Best practice: BP Annual Report and Form 20-F 2011, p. 196}

\section{Figuur 5 Best practice: RBS Group Annual Report 2011, p. 415}

\begin{tabular}{|c|c|c|c|c|c|c|}
\hline \multirow[t]{2}{*}{ Assets and liabilities held for sale included in the divisional segments above } & & & \\
\hline & $\begin{array}{lll}\text { Assets } \\
\mathrm{fm}\end{array}$ & $\begin{array}{lll}\text { Labilites } \\
\mathrm{fm}\end{array}$ & $\begin{array}{cccc}\text { Assots } \\
\text { Am }\end{array}$ & vinteg & Asses & 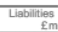 \\
\hline UK Retail & 7,048 & 8,808 & - & - & - & $=$ \\
\hline UK Corporate & 11,661 & 12.977 & - & - & - & \\
\hline Global Transaction Services & 66 & - & 251 & 549 & - & \\
\hline Global Banking \& Markets & 431 & 117 & 19 & - & 9 & \\
\hline Centre & 136 & 2 & - & - & - & - \\
\hline Non-Core & 5,670 & 1,779 & 11,639 & 8,404 & 18,532 & 18,886 \\
\hline RFS Holdings minority interest & 438 & 312 & 575 & 475 & 1 & \\
\hline & 25,450 & 23,995 & 12,484 & 9,428 & 18,542 & 18.890 \\
\hline
\end{tabular}


Tabel 12 Weergave resultaat beëindigde bedrijfsactiviteiten in de winst-en-verliesrekening

\begin{tabular}{|l|r|r|}
\hline & n & $\%$ \\
\hline Resultaat na belastingen als één bedrag & 14 & 88 \\
\hline Resultaat na belastingen met uitsplitsing & 2 & 12 \\
\hline Totaal & 16 & 100 \\
\hline
\end{tabular}

\subsection{Empirisch onderzoek en best practices}

4.2.1 Frequentie van voorkomen van beëindigde bedrijfsactiviteiten In 16 jaarrekeningen is informatie opgenomen over beeindigde bedrijfsactiviteiten. De onderstaande uitkomsten hebben betrekking op deze jaarrekeningen. Voor deze jaarrekeningen is onderzocht in hoeverre aan de presentatieen toelichtingsvoorschriften van IFRS 5 inzake beëindigde bedrijfsactiviteiten is voldaan. Bij het onderzoek hiervan is geen rekening gehouden met een tolerantie, zoals wij die wel hanteerden bij de evaluatie van de bevindingen van ons onderzoek naar de toelichting van activa bestemd voor verkoop. Reden is dat door de definitie van beëindig- de bedrijfsactiviteiten ('een afzonderlijke belangrijke bedrijfsactiviteit of geografisch bedrijfsgebied') mag worden verondersteld dat de toelichting hiervan materiële informatie betreft.

\subsubsection{Weergave resultaat beëindigde bedrijfsactiviteiten in de winst-en-verliesrekening}

Een onderneming moet van beëindigde bedrijfsactiviteiten één bedrag in het 'statement of comprehensive income' vermelden (IFRS 5.33a). Dat bedrag betreft het totaal van:

- het resultaat na belastingen van beëindigde bedrijfsactiviteiten als gevolg van de operationele beëindigde bedrijfsactiviteiten; en

- het resultaat na belastingen als gevolg van de eventuele herwaardering naar reële waarde minus verkoopkosten of als gevolg van het afstoten van de activa of disposal groepen die de beëindigde bedrijfsactiviteiten vormen.

In alle 16 jaarrekeningen is in de winst-en-verliesrekening door middel van één bedrag het totaalresultaat van beeindigde bedrijfsactiviteiten opgenomen. Slechts twee jaarrekeningen bevatten tevens de uitsplitsing van het resultaat na belastingen (zie tabel 12).

\section{Figuur 6 Best practice: ING Group Annual Report 2011, p. 91}

\begin{tabular}{|c|c|c|c|c|}
\hline \multicolumn{5}{|l|}{ for the years ended 31 December } \\
\hline amounts in millions of euros & 2011 & 2010 & 2009 & 2009 \\
\hline \multicolumn{5}{|l|}{ Continuing operations } \\
\hline Interest income banking operations & 64,649 & 68,334 & 79,850 & \\
\hline Interest expense banking operations & $-51,200$ & $-55,011$ & $-67,475$ & \\
\hline Interest result banking operations 35 & 13,449 & 13,323 & & 12,375 \\
\hline Gross premium income 36 & 27,198 & 27,786 & & 30,248 \\
\hline Investment income 37 & 6,808 & 7,463 & & 3,158 \\
\hline Net result on disposals of group companies 38 & 855 & 310 & & 287 \\
\hline Gross commission income & 6,003 & 5,868 & 6,551 & \\
\hline Commission expense & $-1,966$ & $-1,720$ & $-2,311$ & \\
\hline Commission income 39 & 4,037 & 4,148 & & 4,240 \\
\hline Valuation results on non-trading derivatives 40 & 1,674 & -467 & & $-4,743$ \\
\hline Net trading income 41 & 209 & 627 & & 1,125 \\
\hline Share of result from associates 6 & 221 & 311 & & -463 \\
\hline Other income 42 & 1,343 & 604 & & 701 \\
\hline Total income & 55,794 & 54,105 & & 46,928 \\
\hline Gross underwriting expenditure 43 & 33,716 & 45,015 & 50,129 & \\
\hline Investment result for risk of policyholders & 1,246 & $-10,492$ & $-17,736$ & \\
\hline Reinsurance recoveries & $-1,875$ & $-1,721$ & $-1,700$ & \\
\hline Underwriting expenditure 43 & 33,087 & 32,802 & & 30,693 \\
\hline Addition to loan loss provisions 5 & 1,670 & 1,751 & & 2,973 \\
\hline Intangible amortisation and other impairments 44 & 379 & 1,070 & & 524 \\
\hline Staff expenses 45 & 7,556 & 7,692 & & 7,271 \\
\hline Other interest expenses 46 & 528 & 786 & & 711 \\
\hline Other operating expenses 47 & 6,465 & 6,076 & & 6,593 \\
\hline Total expenses & 49,685 & 50,177 & & 48,765 \\
\hline Result before tax from continuing operations & 6,109 & 3,928 & & $-1,837$ \\
\hline Taxation 48 & 1,365 & 1.228 & & -613 \\
\hline Net result from continuing operations & 4,744 & 2,700 & & $-1,224$ \\
\hline \multicolumn{5}{|l|}{ Discontinued operations } \\
\hline Net result from discontinued operations 25 & 114 & 216 & & 100 \\
\hline $\begin{array}{l}\text { Net result from disposal of discontinued } \\
\text { operations } 25\end{array}$ & 995 & & & \\
\hline Total net result from discontinued operations 25 & 1,109 & 216 & & 100 \\
\hline $\begin{array}{l}\text { Net result from continuing and discontinued } \\
\text { operations (before minority interests) }\end{array}$ & 5,853 & 2,916 & & $-1,124$ \\
\hline
\end{tabular}




\section{Tabel 13 Analyse resultaat beëindigde bedrijfsactiviteiten in de toelichting}

\begin{tabular}{|l|r|r|}
\hline & n & $\%$ \\
\hline $\begin{array}{l}\text { Analyse van resultaat beëindigde bedriffsactiviteiten na } \\
\text { belasting in toelichting voor alle activiteiten }\end{array}$ & 8 & 50 \\
\hline $\begin{array}{l}\text { Analyse van resultaat beëindigde bedriffsactiviteiten } \\
\text { beperkt tot deel van de activiteiten }\end{array}$ & 3 & 19 \\
\hline $\begin{array}{l}\text { Geen analyse van resultaat beëindigde bedriffsactivi- } \\
\text { teiten na belasting in toelichting }\end{array}$ & 5 & 31 \\
\hline Totaal & 16 & 100 \\
\hline & & \\
\hline Bij analyse informatie over: & & \\
\hline $\begin{array}{l}\text { - Resultaat uit operationele activiteiten uit beëindigde } \\
\text { bedrijfsactiviteiten }\end{array}$ & 8 & 50 \\
\hline $\begin{array}{l}\text { - Belasting over resultaat operationele activiteiten uit } \\
\text { beëindigde bedrijfsactiviteiten }\end{array}$ & 7 & 44 \\
\hline $\begin{array}{l}\text { - Resultaat uit desinvesteringen of herwaardering naar } \\
\text { reële waarde minus verkoopkosten }\end{array}$ & 8 & 50 \\
\hline $\begin{array}{l}\text { - Belasting over resultaat uit desinvesteringen of her- } \\
\text { waardering naar reële waarde minus verkoopkosten }\end{array}$ & 6 & 38 \\
\hline
\end{tabular}

De winst-en-verliesrekening van ING Group geeft afzonderlijk inzicht in het resultaat na belastingen dat op de operaties zelf is behaald en het resultaat na belastingen dat is behaald op de verkoop.

\subsubsection{Analyse resultaat beëindigde bedriffsactiviteiten in de toelichting}

De jaarrekening dient een analyse te bevatten van deze resultaten en de gerelateerde winstbelastingen (IFRS $5.33 \mathrm{~b}$ ). Deze analyse mag worden opgenomen in de toelichting of in de winst-en-verliesrekening zelf. Indien de presentatie plaatsvindt in de winst-en-verliesrekening moet de uitsplitsing worden gepresenteerd in een rubriek aangemerkt als betrekking hebbend op beëindigde bedrijfsactiviteiten.

Deze analyse dient in te gaan op (IFRS 5.33b):

- de opbrengsten, de lasten en het resultaat vóór belastingen van beëindigde bedrijfsactiviteiten;

- de gerelateerde last uit hoofde van winstbelastingen;

- het resultaat na belastingen als gevolg van de eventuele herwaardering naar reële waarde minus verkoopkosten of als gevolg van het afstoten van de activa of disposal groepen die de beëindigde bedrijfsactiviteiten vormen; en

- de daarmee verband houdende lasten uit hoofde van winstbelastingen.

De presentatie van de resultaten van beëindigde activiteiten dient duidelijk gescheiden plaats te vinden van de voortgezette bedrijfsactiviteiten. De uitsplitsing is niet vereist voor een disposal groep die een nieuw verworven
Tabel 14 Weergave winst per aandeel van beëindigde bedrijfsactiviteiten

\begin{tabular}{|l|r|r|}
\hline & $\mathrm{n}$ & $\%$ \\
\hline Weergave winst per aandeel in de jaarrekening & 15 & 94 \\
\hline Geen weergave winst per aandeel & 1 & 6 \\
\hline Totaal & 16 & 100 \\
\hline
\end{tabular}

\section{Tabel 15 Weergave kasstromen beëindigde bedrijfsactiviteiten in het kasstroomoverzicht en de toelichting}

\begin{tabular}{|l|r|r|}
\hline & $n$ & $\%$ \\
\hline $\begin{array}{l}\text { Kasstromen beëindigde bedrifsactiviteiten met rubrice- } \\
\text { ring in het kasstroomoverzicht }\end{array}$ & 7 & 44 \\
\hline $\begin{array}{l}\text { Kasstromen beëindigde bedrijfsactiviteiten met rubrice- } \\
\text { ring in de toelichting }\end{array}$ & 5 & 31 \\
\hline $\begin{array}{l}\text { Kasstromen beëindigde bedrifsactiviteiten zonder rubri- } \\
\text { cering }\end{array}$ & 1 & 6 \\
\hline Geen weergave kasstromen beëindigde bedrifsactiviteiten & 3 & 19 \\
\hline Totaal & 16 & 100 \\
\hline & & \\
\hline $\begin{array}{l}\text { Weergave van rubricering (een of meer) van kasstro- } \\
\text { men met betrekking tot: }\end{array}$ & & \\
\hline - operationele activiteiten & 11 & 69 \\
\hline - investeringsactiviteiten & 12 & 75 \\
\hline - financieringsactiviteiten & 10 & 63 \\
\hline
\end{tabular}

dochtermaatschappij betreft die op de overnamedatum voldoet aan de criteria bestemd voor verkoop (IFRS 5.39).

In geen enkele jaarrekening is deze analyse volledig in de winst-en-verliesrekening zelf opgenomen. In twee jaarrekeningen is in de winst-en-verliesrekening wel het totaalresultaat van beëindigde bedrijfsactiviteiten gesplitst in het resultaat na belastingen van beëindigde bedrijfsactiviteiten en het resultaat van het afstoten van beëindigde bedrijfsactiviteiten (zie tabel 12). Tabel 13 laat zien welke informatie over de samenstelling van resultaat van beeindigde bedrijfsactiviteiten is opgenomen in de jaarrekening.

In elf $(69 \%)$ van de 16 onderzochte jaarrekeningen waarin het resultaat uit beëindigde bedrijfsactiviteiten in de winst-en-verliesrekening is opgenomen, is een analyse hiervan opgenomen in de toelichting. Hiervan wordt in drie jaarrekeningen $(19 \%)$ aandacht besteed an een deel van de activiteiten. In vijf jaarrekeningen ( $31 \%)$ is geen analyse aanwezig. Uit de informatie in de jaarrekeningen is niet altijd met zekerheid vast te stellen wat de reden is voor het ontbreken van een dergelijke analyse. In de 
meeste gevallen lijkt het geen materiële resultaten te betreffen. Overigens kan dit erop duiden dat sommige beeindigde bedrijfsactiviteiten ten onrechte worden gepresenteerd als beëindigde bedrijfsactiviteiten in de zin van IFRS 5 . Immers, IFRS 5 bepaalt dat sprake moet zijn van een afzonderlijke belangrijke bedrijfsactiviteit of geografisch bedrijfsgebied voor classificatie als beëindigde bedrijfsactiviteiten. Als er daadwerkelijk sprake is van een afzonderlijke belangrijke bedrijfsactiviteit of geografisch bedrijfsgebied, zou mogen worden verondersteld dat de analyse hiervan materiële informatie betreft.

\subsubsection{Weergave winst per aandeel van beëindigde bedrijfsactiviteiten}

Ondernemingen dienen de winst per aandeel te vermelden voor de beëindigde bedrijfsactiviteiten (IAS 33.68). In 15 jaarrekeningen (94\%) is hieraan voldaan (zie tabel 14). In één jaarrekening (6\%) is de winst per aandeel niet weergegeven. Dit lijkt samen te hangen met de zeer beperkte omvang van het resultaat op beëindigde bedrijfsactiviteiten. Daarnaast dient een onderneming de cijfers van het resultaat uit beëindigde bedrijfsactiviteiten met betrekking tot voorgaande perioden op te nemen. In alle 16 jaarrekeningen zijn de vergelijkende cijfers ook opgenomen.

\subsubsection{Weergave kasstromen beëindigde bedrijfsactiviteiten}

Ondernemingen moeten informatie geven over de kasstromen van beëindigde bedrijfsactiviteiten. De nettokasstromen inzake de operationele, investerings- en financieringsactiviteiten van beëindigde bedrijfsactiviteiten moeten worden vermeld (IFRS 5.33c). Deze informatie kan worden opgenomen in de toelichting of kan worden gepresenteerd in het kasstroomoverzicht zelf. Deze informatie is niet vereist voor disposal groepen die recent overgenomen dochterondernemingen betreffen en die aan de criteria voldoen om bij overname te worden geclassificeerd als bestemd voor verkoop (IFRS 5.39).

Een uitsplitsing naar nettokasstromen uit operationele, investerings- en financieringsactiviteiten van beëindigde bedrijfsactiviteiten is opgenomen in 12 jaarrekeningen (75\%). Van de 16 jaarrekeningen geven drie jaarrekeningen $(19 \%)$ niet het vereiste inzicht in de nettokasstroom van beëindigde bedrijfsactiviteiten. In één jaarrekening $(6 \%)$ is wel de nettokasstroom van beëindigde bedrijfsactiviteiten toegelicht, maar zonder rubricering naar nettokasstromen uit operationele, investerings- en financieringsactiviteiten (zie tabel 15). Uit de informatie in de jaarrekeningen is

\section{Figuur 7 Best practice: Philips Group Annual Report 2011, p. 124}

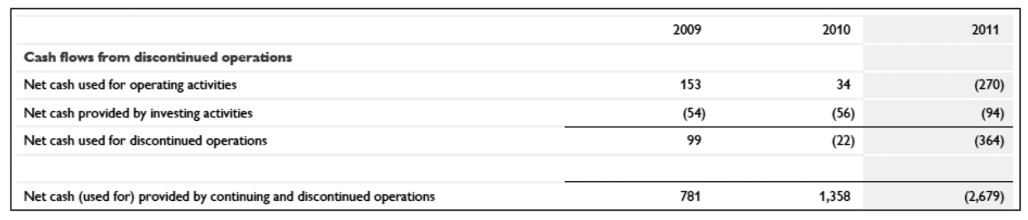

niet altijd met zekerheid vast te stellen wat de reden is voor het ontbreken van deze informatie. Wel valt op dat het jaarrekeningen betreft die ook de resultaatanalyse niet hebben opgenomen. Eerder werd al aangegeven dat het hierbij lijkt te gaan om informatie die niet materieel wordt geacht.

Met betrekking tot de door IFRS 5 vereiste kasstroominformatie (IFRS 5.33c) bevat de jaarrekening van Philips een goed voorbeeld. Hierin staat een separaat overzicht inzake beëindigde bedrijfsactiviteiten met de nettokasstroom per soort activiteit. Hierdoor is in één oogopslag meer informatie zichtbaar en zijn zowel de afzonderlijke activiteiten als het totaal van beëindigde bedrijfsactiviteiten weergegeven.

\section{Conclusies en afsluitende opmerkingen}

Dit onderzoek heeft zich toegelegd op de informatieverschaffing over beëindigde bedrijfsactiviteiten en activa (of disposal groepen) bestemd voor verkoop. Hierbij zijn de presentatie- en toelichtingsvoorschriften zoals opgenomen in IFRS 5 als primair uitgangspunt gehanteerd. Het onderzoek heeft zich gericht op jaarrekeningen over 2011 van ondernemingen uit de FTSE Eurotop 10o. Circa een kwart van deze ondernemingen is afkomstig uit het Verenigd Koninkrijk. Uit het onderzoek komt naar voren dat meer dan de helft van de ondernemingen in haar jaarrekening beëindigde bedrijfsactiviteiten en/of activa (of disposal groepen) bestemd voor verkoop presenteert. Het overgrote deel hiervan presenteert activa (of disposal groepen) bestemd voor verkoop. Beëindigde bedrijfsactiviteiten komen relatief minder vaak voor. Dit zal verband houden met de definitie van beëindigde bedrijfsactiviteiten. Alleen een afzonderlijke belangrijke bedrijfsactiviteit of geografisch bedrijfsgebied komt voor classificatie als beëindigde bedrijfsactiviteiten in aanmerking.

Uit dit onderzoek blijkt met name dat de toelichting van activa (of disposal groepen) bestemd voor verkoop niet in alle gevallen overeenkomt met de in IFRS 5 opgenomen toelichtingsvoorschriften. Mogelijke verklaring hiervoor zou het toepassen van materialiteit bij het opstellen van de jaarrekening kunnen zijn. In de gevallen dat activa (of disposal groepen) bestemd voor verkoop ten opzichte van het totale balanstotaal groter is dan $0,5 \%$ is de naleving veel beter. In de jaarrekeningen waarin activa (of disposal groepen) bestemd voor verkoop relatief groot zijn, is meer toelichting opgenomen.

Bij de toelichting van beëindigde bedrijfsactiviteiten is de toegankelijkheid van de informatie niet in alle gevallen optimaal. Dit wordt mede veroorzaakt door het op verschillende plaatsen in de jaarrekening opnemen van de informatie inzake beëindigde bedrijfsactiviteiten. Daarnaast ontbreekt in diverse jaarrekeningen informatie waardoor het beoordelen van het effect van beëindigde be- 
drijfsactiviteiten op de omvang, timing en onzekerheden van toekomstige kasstromen niet altijd optimaal is. Mogelijk wordt ontbreken van bepaalde informatie veroorzaakt door geringe materialiteit. Overigens kan dit erop duiden dat sommige beëindigde bedrijfsactiviteiten ten onrechte worden gepresenteerd als beëindigde bedrijfsactiviteiten in de zin van IFRS 5 . Immers, IFRS 5 bepaalt dat sprake moet zijn van een afzonderlijke belangrijke bedrijfsactiviteit of geografisch bedrijfsgebied voor classificatie als beeindigde bedrijfsactiviteiten. Als er daadwerkelijk sprake is van een afzonderlijke belangrijke bedrijfsactiviteit of geografisch bedrijfsgebied, zou mogen worden verondersteld dat de toelichting hiervan materiële informatie betreft.
Drs. D. (Dingeman) Manschot RA is director bij het vaktechnisch centrum van Deloitte Accountants B.V. en docent externe verslaggeving aan de Erasmus Universiteit Rotterdam.

I.J. (Ineke) Kuiper MSc EMA RA is werkzaam bij

PricewaterhouseCoopers Accountants N.V. en docent

externe verslaggeving aan de Rijksuniversiteit Groningen.

De auteurs danken de heer S.W. Vervest voor zijn

waardevolle bijdrage aan het empirisch onderzoek.

\section{Noten}

Een index die is samengesteld uit de 100 belangrijkste Europese fondsen. Voor dit onderzoek is gebruik gemaakt van de index per jaareinde 2011.
Het weglaten of oniuist weergeven van posten is van materieel belang indien de weglating of onjuiste weergave, afzonderlijk of gezamenlijk, de economische beslissingen die gebruikers op basis van de jaarrekening nemen, zou kunnen beïnvloeden (IAS 1.7).

\section{Literatuur}

\section{- Blommaert, J.M.J. en M.P. Lycklama à} Nijeholt (2006), Beëindigde bedrijfsactiviteiten en activa bestemd voor verkoop, in: R. Bosman, C. Camfferman en R. Vergoossen (redactie), Het jaar 2005 verslagen Onderzoek jaarverslaggeving ondernemingen (pp. 91-114), Amsterdam/Deventer: Koninklijk NlvRA in samenwerking met Kluwer.
- International Accounting Standards Board (IASB) (2010), International Financial Reporting Standard 5 Non-Current Assets Held for Sale and Discontinued Operations (IFRS 5), IASC Foundation, London.

- International Accounting Standards Board (IASB) (2010), The Conceptual Framework for Financial Reporting, IASC Foundation, London.
- PricewaterhouseCoopers (2011), Manual of Accounting - IFRS 2012, Bloomsbury Professional, London.

- Scott, W.R. (2006), Financial Accounting Theory, 4th edition, Prentice Hall, New Jersey. 
Bijlage 1 Definitieve onderzoekspopulatie (N2)

\begin{tabular}{|c|c|c|}
\hline & Naam & Land \\
\hline 1 & A P Moller - Maersk & Denemarken \\
\hline 2 & Arcelor Mittal & Nederland \\
\hline 3 & Atlas Copco & Zweden \\
\hline 4 & AXA & Frankrijk \\
\hline 5 & $\begin{array}{l}\text { Banco Bilbao Vizcaya Argentaria } \\
\text { (BBVA) }\end{array}$ & Spanje \\
\hline 6 & Banco Santander & Spanje \\
\hline 7 & BASF & Duitsland \\
\hline 8 & Bayer AG & Duitsland \\
\hline 9 & BG Group & Verenigd Koninkrijk \\
\hline 10 & $\mathrm{BP}$ & Verenigd Koninkrijk \\
\hline 11 & British American Tobacco & Verenigd Koninkrijk \\
\hline 12 & Carrefour & Frankrijk \\
\hline 13 & Centrica & Verenigd Koninkrijk \\
\hline 14 & Credit Agricole & Frankrijk \\
\hline 15 & Danone & Frankrijk \\
\hline 16 & Deutsche Telekom & Duitsland \\
\hline 17 & Diageo & Verenigd Koninkrijk \\
\hline 18 & Electricite de France (EDF) & Frankrijk \\
\hline 19 & E.ON & Duitsland \\
\hline 20 & Enel & Italië \\
\hline 21 & Eni & Italië \\
\hline 22 & Fortum & Finland \\
\hline 23 & GDF SUEZ & Frankrijk \\
\hline 24 & Generali & |talië \\
\hline 25 & GlaxoSmithKline & Verenigd Koninkrijk \\
\hline
\end{tabular}

\begin{tabular}{|r|l|l|}
\hline & Naam & Land \\
\hline 26 & Heineken NV & Nederland \\
\hline 27 & Holcim & Zwitserland \\
\hline 28 & HSBC Holdgs & Verenigd Koninkrijk \\
\hline 29 & Iberdrola & Spanje \\
\hline 30 & ING Group CVA & Nederland \\
\hline 31 & Intesa Sanpaolo & Italïe \\
\hline 32 & Koninklijke Philips Electronic & Nederland \\
\hline 33 & Münchener Rueckversicherungs Reg & Duitsland \\
\hline 34 & National Grid & Verenigd Koninkrijk \\
\hline 35 & Nestle & Zwitserland \\
\hline 36 & Repsol-Ypf & Spanje \\
\hline 37 & Rio Tinto & Verenigd Koninkrijk \\
\hline 38 & Royal Bank Of Scotland Group & Verenigd Koninkrijk \\
\hline 39 & SABMiller & Verenigd Koninkrijk \\
\hline 40 & Sanofi & Frankrijk \\
\hline 41 & Siemens AG & Duitsland \\
\hline 42 & Soc Generale De France & Frankrijk \\
\hline 43 & Telecom Italia & Italië \\
\hline 44 & Telefonica & Spanje \\
\hline 45 & Telenor A/S & Noorwegen \\
\hline 46 & Tesco & Verenigd Koninkrijk \\
\hline 47 & Unicredit & Italï̈ \\
\hline 48 & Unilever & Nederland \\
\hline 49 & Volvo & Zweden \\
\hline 50 & Zurich Financial Services & Zwitserland \\
\hline & & \\
\hline
\end{tabular}

